\title{
Exploring the innovative financing techniques of motor vehicle dealerships
}

\author{
Sipho Makgopa \\ University of South Africa, South Africa
}

\begin{abstract}
Keywords
Business performance, complex adaptive theory, content analysis, innovation, motor vehicle financing,

Abstract

Motor vehicle dealership are confronted with an excessive competition and are resorting on innovative techniques to retain customers. The purpose of this paper is to identify different innovative financing techniques being adopted by motor vehicle dealership. A qualitative research method was used to address the research purpose of this paper. A content data analysis was followed in analysing the primary data gathered during the study. The findings of this paper uncovered that different innovative financing techniques are used by motor vehicle dealerships in an attempt to remain competitive. Recommendations to the managers of motor vehicle dealerships and future research directions are provided in this paper.
\end{abstract}

Corresponding author: Sipho Makgopa

Email addresses for the corresponding author: makgoss@unisa.ac.za

First submission received: $5^{\text {th }}$ February 2018

Revised submission received: $15^{\text {th }}$ July 2018

Accepted: 10 $10^{\text {th }}$ September 2018

\section{Introduction}

In the competitive business environments of the 21st Century, organisations have recognised the need to frequently innovate and provide new processes and better services to customers. An organisation can achieve a competitive advantage by possessing resources and capabilities that are unique, valuable, and difficult to imitate by other organisations (Bellini, Dell' Era, Frattini \& Verganti, 2016; Hsu and Ziedonic, 2013). However, the achievement of a competitive advantage depends on the organisation's innovative capabilities and resources (Yanadori and Cui, 2013). Developing and implementing innovation strategies is believed to assist in improving organisations business performance by increasing market share and provide the organisation with competitive advantage (Prajogo, 2016; Gunday, Ulusoy, Kilic and Alpkan, 2011). Therefore, innovation is important to drive a market driven approach that contributes towards competitive advantage over competitors and business growth.

Competition between organisations in the motor vehicle industry is also increasing with the introduction of new brands in South Africa and in other parts of the world, and these organisations operate in a dynamic and competitive business environment (Van Donder, Petzer \& van Zyl, 2017). This paper aims to fill the gap in service innovation literature as the majority of previous literature has focused much on product innovations.

The next section outlines the purpose of this research.

\section{The purpose of the study}

The purpose of this paper is to identify different innovative financing techniques being adopted by motor vehicle dealership (MVDs) as part of service innovation.

\section{Theoretical background and literature review}

The next section provides relevant theoretical background and literature review of previous studies on innovation.

\subsection{Definitions of relevant terms}

The concepts innovation and business performance are provided in the next sub-sections. 


\subsubsection{Innovation}

Innovation is defined as the degree to which retailers operating in a given market adopt new ideas for service; and they attempt to gather consumer assessment of the number of innovations adopted, moment of adoption and consistency of the retailer's willingness to innovate over time (Ruiz-Molina, 2017). According to Cheng, Yang and Sheu (2014) there are various types of innovation, namely, product innovation, process innovation, organisational innovation and service innovation which can be used to achieve optimal business performance in different industries. Product innovations are based on the knowledge or technology applied to manufacture of the product whereas process innovations focus on production or the stages required to combine new materials in order to produce a finished product, reducing costs or improving efficiency (Ruiz-Molina, Gil-saura, \& Servera-Francés 2015). Product innovation involves adding new ideas and features on existing product line offered by the organisation, process innovation involves changes on how products or services are created and delivered to customers, and organisational innovation involves new changes that are made within the organisation (Makhitha, Can't \& Theron, 2016). Service innovation is defined as new developments in processes, activities and methods followed in delivering the organisation's existing services (Prajogo \& Oke, 2016). The focus of this study will be on service innovation in the case of MVDs. For the purpose of this study the provided definition is considered to be relevant.

\subsubsection{Business performance}

Business performance (BP) is conceptualised business performances as the measures that determines how well an organisation manages its internal resources and adapts to its external business environments into financial performance which can be in the form of increased sales, profit, stock market shares, return on equity, and non-financial performance measures such as reputation, competitiveness, branding and quality (Al-Ansari, Pervan \& Xu, 2013). Lakhal, Lakhal and Cheurfi (2014) suggested that organisational performance involves how well an organisation achieves its market-oriented objectives as well as its financial goals. For the purpose of this research, business performance both financial and nonfinancial measures that explains the results of innovative activities of MVDs. An example of non-financial performance includes organisational reputation. Organisational image refers to the reputation associated with their organisation's name for the range of products, business activities and services marketed to customers of products that were marketed across the categories (Tracey \& Phillips, 2016). According to Boivie, Graffin and Gentry (2016) organisational reputation is attribute specific, including how the organisation treats stakeholders, overall product or service quality in the industry.

\subsubsection{Motor vehicle financing}

A motor vehicle finance often known as car loan refers to the range of financial products available to cover the sum of money a consumer or entity can borrow in order to buy a car with an arrangement other than a full-cash single lump payment, and this money includes the interest charged on the credit amount (Shende, 2014).

\subsubsection{The complexity adaptive theory}

The Complex Adaptive Systems (CAS) Model was derived from a scientific theory of complexity. Rogers, Medina, Rivera, and Wiley (2005) argued that the complex adaptive systems theory (CAS) can be utilised together in the construction of predictive or applied hybrid models of induced change in population behavior. The end results of complex adaptive systems are the manifestation out of disorganisation into a more ordered system, with more adaptable patterning and better fit. In such interventions, differentiated zones may act as catalysts for the adoption of innovation. According to James Gleick, the inspiration for complexity science can be traced to John von Neumann's dynamic weather system models of the 1950s at the Institute for Advanced Study in Princeton, New Jersey, an effort that, in turn, goes back to the work of the eighteenth-century philosopher-mathematician Laplace (Gleick, 1987). Most real business contexts are charaterised to be complex.

Gummesson (2008) pointed out that the involvement of several participants (such as customers, suppliers and partners) makes value co-creation a complex process. The development of new frameworks is therefore required to analyse value creation to customers as a process resulting from the many to many relationships between all the participants involved (stakeholder centricity) rather than as the dyadic 
relationships between a supplier and customer (see Polese, Mele ${ }^{\circ} \&$ Gummesson, 2017). CAS tend to function through a great deal of communication and collaboration, little hierarchical organisation, and staff members who are capable of generating innovation (Sturmberg et al., 2012); which implies that the individual parts (or teams, in a multidisciplinary service) are adaptive, responsive to internal and external changes linked to the services. According to Alaa and Fitzgerald (2013) CAS theory implies that agents that form the system continuously interact with each other and with the global environment to form stable, global patterns that suit the current settings in the system and the environment. For the purpose of this study, CAS theory will be adopted as the focus is not only on innovation, but stakeholder centricity (suppliers of motor vehicle financial options) and collaborations between participants (motor vehicle dealerships and customers).

\subsection{Literature review of previous studies}

Most of previous studies on innovation are conducted in other parts of the world such as Asia, Australia, China, Europe, France, Italy, Portugal, United States, United Kingdom with few studies conducted from South African perspective. In addition, these previous studies are conducted in other sectors of the economy such as manufacturing, engineering, construction and SMEs rather than exclusively in the motor vehicle retail/dealership sector which present a gap for the proposed study. Innovation studies, particularly, service innovation studies conducted in manufacturing and service industries, (Rangus \& Slavec, 2017; Parris et al., 2016; Khan \& Naeem, 2016; Zhang et al., 2015; Chang et al., 2014; Kindström \& Kowalkowski, 2014; Chong \& Zhou, 2014; Kindström, 2013; Salunke et al., 2013; Thakur \& Hale, 2013; Ordanini et al., 2013; Janeiro et al. 2013; Pesämaa et al., 2013).

Most these studies are conducted in manufacturing sector rather than service sector. For example, Rangus and Slavec (2017) investigated the relationship between organisational characteristics, organisational service innovation and business performance of 421 manufacturing and service organisations, however, the service organisations included in Rangus et al. (2017) study exclude organisations operating in a motor vehicle retail. Parris et al. (2016) explored on the challenges experienced in implementing service innovation in the context of athletic department, and this study uncovered that coordinating adoption, obtaining commitment (buy-in), developing competency, estimating costs and developing contents as key challenges. In another service innovation study, Khan and Naeem (2016) investigated service innovation within telecommunication service industry by determining the relationships between quality practices, service innovation and business performance.

In another studies, Zhang et al. (2015) investigated the effect of customer-orientation, supplier collaboration and technological capability on innovation of service and manufacturing organisations. Kindström and Kowalkowski (2014) investigated the nature and characteristics of the business model elements in product-centric organisations required for successful service innovation. Kindström et al. (2013) explored on service innovation in product-centric industry, the results revealed that successful innovative service delivery is dependent on organisational capabilities. Thankur and Hale (2013) investigated the influence of service innovation on the financial and non-financial performance of projectoriented organisations. On the other hand, Janeiro et al. (2013) investigated service innovation from a different dimension by determining the links between service innovations and universities as sources of information of innovation. Monga, Chaudhary and Tripathi (2012) investigated how customer and potential customer think about a given brand of car and what are the possible factors guiding a possible purchase. Similar study was conducted by Shende (2014) in in order to understand consumer behavior in making their purchase decisions of motor vehicles in a passenger segment in India.

From the preceding literature, it is apparent that few studies have been conducted in service sector, specifically, motor vehicle retail sector and the focus was on manufacturing industry, groceries retail stores, and fashion retail not motor vehicle retail which creates a gap to be filled by the proposed study. Secondly, some of the preceding studies focused much on consumer behaviour (Shende, 2014; Monga et al., 2012) rather than financing options. Prajogo (2016) examined the effect of human capital (HC) on service innovation advantage (SIA) and business performance (BP), and how external environmental factors influence these relationships and the focus was on Australian manufacturing industry. In addition, Sethibe and Steyn (2016:2) pointed out that a research in organisation performance has to be at the core of management research, with little research done with regard to suitable measures to assess the influence of 
innovation activities, hence, this study endeavour to fill that gap, by exploring on the innovative motor vehicle financing techniques used by MVDs in order to improve business performance and remain competitive.

\section{The next section provides the contribution of this study.}

\section{Contributions of the study}

In reviewing the secondary research available, it is clear that service innovation is not widely addressed in the South African context, specifically in the motor vehicle industry. This study contributes to literature on the topic by highlighting current service innovation initiatives, particularly, innovative motor vehicle financing techniques, used by MVDs, for the purpose of improving business performance and remaining competitive. Furthermore, this study can benefit MVDs by expounding the main reasons for consideration and suggesting careful utilisation of resources in planning and creating more innovation financial products. This work can assist marketers and managers to make better decisions associated with planning and executing innovative financial options that could be of benefit to both internal and external stakeholders. Lastly, this paper provides directions for future research on the topic.

The next section outlines the research methodology followed to accomplish the research purpose of this study starting with the research design, target population, sampling frame and technique, data collection, and data analysis method used.

\section{Research methodology}

This section provides the research methodology followed to realise the research purpose of this study starting with the research design, target population, sampling frame and technique, data collection, and data analysis method used.

\subsection{Research philosophy and research Design}

In this study an interpretive research philosophy is used in generating the meaning from the primary data. Neuman (2011) pointed out that interpretive research philosophy is considered as a systematic analysis of socially meaningful action through the direct detailed observation of people in a natural setting in order to arrive at the understandings and interpretations of how people create and maintain their social world. Interpretive researchers strive to study a meaningful social action, not just the external or observable behaviour of people. In this study, the service innovation, particularly, innovative financing options of MVDs are explored to generate an understanding.

An exploratory qualitative approach was followed in order to address the research objective. Malhotra (2010) pointed that an exploratory research design is useful when the researcher requires more information about a specific problem, an opportunity or a phenomenon. The qualitative research approach was chosen for a number of reasons: participants' perspectives and experiences were emphasised; it took into account participants' interpretation and it allows for flexibility. More specifically, the aim of using a qualitative approach was to collect data more effectively and to gain richer information by enabling participants to also express their opinions and share their experiences with regard to the innovative motor vehicle techniques being implemented by MVDs.

\subsection{Target population}

The target population of interest for the current study was the MVDs operating in South Africa. South Africa was chosen due to its convenience and accessibility for the researcher. In addition, one country was selected, as the aim of the study was not to be representative, but rather to enable other researchers to explore on innovative motor vehicle techniques of MVDs. Managers or sales executives of MVDs were chosen as the unit of analysis. In this study, managers and sales executives of MVDs were interviewed since they were holders of the data needed to answer the research questions of this research. Thirteen participants participated in this study, of which eight of these participants were managers of MVDs and five were senior sales executives involved in sales and financing of motor vehicles in their respective MVDs. This was sufficient to generate finding, as is permitted in qualitative study to use the researcher is permitted in a qualitative study to use a small sample (Brynard \& Hanekom (2006). 


\subsection{Sample frame}

Retail Motor Industry (RMI) member list was used as a sample frame in the current study, to select registered accredited MVD included in the study. The MVDs operating within the borders of Gauteng province, South Africa in the Gauteng province, South Africa were contacted. Tustin et al. (2005) indicated that the sample frame may be a telephone directory, customer list, and research company databases, a list of e-mails addresses or even geographic maps. The researcher used Google, a well-known search engine on the Internet to search for list of MVDs in South Africa from RMI database organisation's website (Retail Motor Industry, 2016). RMI member list contains the contact details of registered accredited MVDs operating in of South Africa. The researcher used the e-mail addresses and telephone numbers obtained from RMI member list to contact MVDs to get contact details of personnel (involved in sales and motor vehicle finance). Based on the contact details provided by the MVDs managers, other participants were contacted via e-mails to request their consents to participate and in-depth interviews were scheduled.

\subsection{Sample technique}

A purposive sampling method was used in this study. Purposive sampling method means that participants are selected because of some defining characteristics that make them the holders of the data needed for the study (Tustin et al., 2005). The population can be defined as the total group of persons or entities from whom information is required (Tustin et al., 2005). The target population refers to the collection of elements that possess information sought by the researcher (Malhotra, 2010). A purposive sampling method was used in order to concentrate on the participants, in this case sales and financial officers who possess the richest information based on their roles in their respective organisations, which presented a possibility to answer research questions of this research. Twenty participants from different MVDs were target, however, thirteen participants from twenty different MVDs selling both new and used vehicles participated in this study.

\subsection{Data collection}

In-depth semi-structured interviews were used to collect the primary data in the current study using audio recorder. The primary data was collected using semi-structured in-depth interviews. According to Malhotra (2010) an in-depth interview refers to an interaction between an individual interviewer with a single participant, and the semi-structured depth interviews allow the interviewer to uncover underlying motivations and probe on a particular topic. The researcher used a research guide containing research question topics during the interviews with participants. The researcher had to arrange a time and date most suitable for an interview with participants. All participants were briefed telephonically about the research objectives and the research topic was emailed to the participants. This was done to ensure that the researcher, as well as the participants, were at ease, and prepared for the interview, as well as to build rapport and relationship before the data collection began. Before the interviews could begin, the purpose for the research was explained to the participant to put participants at ease.

\subsection{Data analysis}

In this research the qualitative content analysis was used, as it perfectly suited for the purpose of this study, which aimed to explore on the innovative motor vehicle techniques of MVDs. In addition, Atlas ti. Version 7 computer software was utilsed in generating themes. During the data collection period, the transcriptions of the interviews were analysed. The trustworthiness or validity of the qualitative data was exercised in data analysis to avoid biasness in interpreting the data.

The next section presents findings of this paper supported by quotations derived from participants' verbatim during in-depth interviews.

\section{6. $\quad$ Findings}

The research objective of this paper aimed to identify different innovative financing techniques being adopted by MVDs as part of service innovation. In order to address this research objection, the following question was asked, namely; What are the type of innovative financing techniques being used in MVDs? Participants indicated that motor vehicle dealerships develop and implement different innovative motor vehicle financing methods in order to meet customers' financial situations and make 
offerings appeal to these customers. The following quotes were cited from the verbatim of the participants:

"Currently we are offering an agility finance which is tailor-made to suit customers' pockets. With agility customers choose the deposit they can afford and 36 months payments and a guaranteed value on the vehicle. The value of the vehicle financed through Agility finance will not fall below the agreed amount at the end of an Agility agreement." (\#Participant 4)

"With agility customers have an option after 36 months to drive a new model at the guaranteed value on the previous model" (\#Participant 6)

"We are currently advertising interest rate on our new motor vehicle. We subsidies 2 percent on the current interest rate in order to make our vehicle offers affordable to customers." (\#Participant 7)

In addition, the participants alluded that the also use and motor vehicle financing methods which include cashback option, fixed interest rate and trade in assistance in line with customers' financial needs and lifestyle. The following quotes were taken from participants' verbatim:

"Sometimes in our dealership we offer trade-in assistance. With trade assistance the dealership is pays extra money to assist customers in trading in their vehicles for new model vehicle in order to push sales." (\#Participant 1)

"We offer trade-in assistance where the dealership pays a certain amount on the vehicle used as a trade in and recover the same amount from the motor vehicle manufacturer, on the provision that the dealership submits the proof to show that the customer did actual trade in a car." (\#Participant 3)

"In our dealership we offer financial options that meet customers' pockets where customers can choose the pay a deposit or not to pay it and choose number of instalments, choose to drive the car for certain kilometres and trade in the same vehicle agreed mileage for a new vehicle model that suits their lifestyle." (\#Participant 8)

"Currently we are offering a R30 000 trade-in assistance towards structuring a sales deal on our new models (Participant mentioned brand motor vehicle model line) (\#Participant 9)

"In our dealership we often offer cash back on any purchase of motor vehicle models. When advertise as cash back it is usually independent of whether the customer is trading in his or her car or not." (\#Participant 12)

Moreover, participants pointed out that despite the mention motor vehicle financing options, to remain competitive and make motor vehicle purchase affordable to customers there are other options which can be adopted which involve structure of the loan term and ballon payment option. The following quotes are cited from participants' verbatims:

"Customers can pay at least 10 percent deposit in order to reduce repayment instalments." (\#Participant 5)

"We offer customers, a personal contract purchase vehicle financing where consumers pay a minimum deposit and monthly payments, but instead of paying off the total retail value of the vehicle, they actually pay off the vehicle depreciation over a term of 2-3 years." (\#Participant 9)

"In our dealership we allow customers to pay at least 10-20 percent on the car being purchased which in turn impact on term of repayments." (\#Participant 10)

"Our customers have an option to choose term of repayments of 60 months or 72 months." (\#Participant 13)

".... in cases where customers based on the affordabity test argue that the repayment instalments are high, these customers can take a balloon amount which can be 20 or 30 percentage on the principal debt." (\#Participant 11)

"In addition to our financing options, in our dealership were offer customers 30 percentage balloom payment to be paid at the end of loan term." (\#Participant 13)

Based on the findings of this paper, the following conclusions and discussions are provided in the next section.

\section{Conclusions and discussions}

This paper aimed to identify different innovative financing techniques being adopted by motor vehicle dealership as part of service innovation. The findings of this paper revealed that motor vehicle retailers develop innovative motor vehicle financing methods or techniques in order to remain competitive. These innovative financing techniques includes options such as cash back option, subsidising interest rates, allowing customers to choose loan term that suits the financial pockets, allowing customers choose the deposit they can afford, personal contract urchase and trade-in assistance towards structuring a sales deal. These finding brings insight by introducing financial techniques to service innovation literature as it was never investigated in the previous studies. Secondly, the findings of this study supports the view that innovation contributes towards improved business performance. In addition, these

www.jbrmr.com A Journal of the Academy of Business and Retail Management (ABRM) 
findings supports the results of previous studies by Khan and Naeem (2016) and Thankur and Hale (2013) that discovered that there existent of a positive influence of service innovation on the financial and nonfinancial performance.

\section{Managerial implications}

Managers of motor vehicle dealerships should encourage internal employees to be creative to come up with new innovative financial techniques. Sufficient resources should be allocated to support brainstorming sessions to stimulate new ideas that could contribute towards innovation. In addition, managers of motor vehicle dealerships should keep on monitoring international environment to identify any new financial techniques that are being introduced by international motor vehicle dealerships in order to assess if could be adopted in different contexts.

\section{Directions for future research}

This study explored innovative financing techniques of MVDs in one province in South Africa using a qualitative research approach, therefore, future research can be carried-out in other provinces and other parts of the world using mixed method research approach in order to quantify the results. The generalisability of the findings of the study is also limited given the nature of sample used in this study, and it remains for future studies to determine whether these results will hold for a larger cross-section of organisations and similar research approach can be followed in other countries. Finally, future study can focus on new financing techniques that can be adopted in the future to make motor financing affordable to customers.

\section{References}

Alaa, G. and Fitzgerald, G. (2013). Re-conceptualizing agile information systems development using complex adaptive systems theory. Emergence: Complexity and Organization, 15(3).

Al-Ansari, Y., Pervan, S. and Xu, J. (2013). Innovation and business performance of SMEs: the case of Dubai. Education, Business and Society: Contemporary Middle Eastern Issues, 6(3/4):162-180.

Bellini, E., Dell'Era, C., Frattini, F. and Verganti, R. (2016). Design-Driven Innovation in Retailing: An Empirical Examination of New Services in Car Dealership. Creativity and Innovation Management.

Boivie, S., Graffin, S.D. and Gentry, R.J. (2016). Understanding the direction, magnitude, and joint effects of reputation when multiple actors' reputations collide. Academy of Management Journal, 59(1):188-206.

Brynard, P.A. and Hanekom, S.X. (2006). Introduction to research in management related field. $2^{\text {nd }}$ Edition. Van Schaik, South Africa.

Chang, W., Franke, G.R., Butler, T.D., Musgrove, C.F. and Ellinger, A.E. (2014). Differential mediating effects of radical and incremental innovation on market orientation-performance relationship: a meta-analysis. Journal of Marketing Theory and Practice, 22(3):235-250.

Cheng, C.C., Yang, C.L. and Sheu, C. (2014). The link between eco-innovation and business performance: a Taiwanese industry context. Journal of Cleaner Production, 64:81-90.

Chong A.Y. and Zhou, L. (2014). Demand chain management: Relationships between external antecedents, web-based integration and service innovation performance. International Journal of Production Economics, 154:48-58.

Gallouj, F. and Savona, M. (2009). Innovation in services: a review of the debate and a research agenda. Journal of evolutionary economics, 19(2):149.

Gummesson, E. (2014). Commentary on "The role of innovation in driving the economy: Lessons from the global financial crisis". Journal of Business Research, 67(1):2743-2750.

Gunday G, Ulusoy G, Kilic K, Alpkan L. (2011). Effects of innovation types on firm performance. International Journal of Production Economics, 133(2).

Hsu, D.H. and Ziedonis, R.H. (2013). Resources as dual sources of advantage: Implications for valuing entrepreneurial-organisation patents. Strategic Management Journal, 34(7):761-781.

Khan, B.A. and Naeem, H. (2016). Measuring the impact of soft and hard quality practices on service innovation and organisational performance. Total Quality Management \& Business Excellence, 1-25.

Kindström, D. and Kowalkowski, C. (2014). Service innovation in product-centric firms: A multidimensional business model perspective. Journal of Business \& Industrial Marketing, 29(2):96-111.

Lakhal, L. (2014). The relationship between ISO 9000 certification, TQM practices, and organizational performance. The Quality Management Journal, 21(3):38-48.

Malhotra, N.K. (2010). Marketing research: an applied orientation. 6th global ed. Upper Saddle River, NJ: Pearson.

Makhitha, K.M., Can't, M and Theron, D. (2016). Business-to-Business Marketing. 1 ${ }^{\text {st }}$ ed. Juta publisher, South Africa. 
Monga, N., Chaudhary, B. and Tripathi, S. (2012). Car Market and Buying behavior-A study on Consumer Perception. International Journal of Research in Management, Economics and Commerce, 2(2):44-63.

Ordanini, A., Parasuraman, A. and Rubera, G. (2014). When the recipe is more important than the ingredients: A qualitative comparative analysis (QCA) of service innovation configurations. Journal of Service Research, 17(2):134-149.

Pantano, E. (2014). Innovation drivers in retail industry. International Journal of Information Management, 34(3):344-350.

Parris, D.L., Bouchet, A., Welty Peachey, J. and Arnold, D. (2016). Change is hard: overcoming barriers to service innovation. Journal of Services Marketing, 30(6):615-629.

Pesämaa, O., Shoham, A., Wincent, J. and Ruvio, A.A. (2013). How a learning orientation affects drivers of innovativeness and performance in service delivery. Journal of Engineering and Technology Management, 30(2):169-187.

Polese, F., Mele, C. and Gummesson, E. (2017). Value co-creation as a complex adaptive process. Journal of Service Theory and Practice, (just accepted).

Prajogo, D.I (2016) Human capital, service innovation advantage, and business performance: The moderating roles of dynamic and competitive environments, International Journal of Operations $\mathcal{E}$ Production Management, 36(9):974 - 994.

Prajogo, D.I. and Oke, A. and Oke, A. (2016). Human capital, service innovation advantage, and business performance: The moderating roles of dynamic and competitive environments. International Journal of Operations \& Production Management, 36(9):974-994.

Rangus, K. and Slavec, A. (2017). The interplay of decentralization, employee involvement and absorptive capacity on firms' innovation and business performance. Technological Forecasting and Social Change.

Rogers, E.M., Medina, U.E., Rivera, M.A. and Wiley, C.J. (2005). Complex adaptive systems and the diffusion of innovations. The Innovation Journal: The Public Sector Innovation Journal, 10(3):1-26.

Ruiz-Molina, M.E., Gil-saura, I. and Servera-Francés, D. (2017). Innovation as a key to strengthen the effect of relationship benefits on loyalty in retailing. Journal of Services Marketing, 31(2).

Salunke, S., Weerawardena, J. and McColl-Kennedy, J.R. (2013). Competing through service innovation: The role of bricolage and entrepreneurship in project-oriented firms. Journal of Business Research, 66(8):1085-1097.

Sethibe, T. and Steyn, R. (2016). Innovation and organisational performance: A critical review of the instruments used to measure organisational performance. The Southern African Journal of Entrepreneurship and Small Business Management, 8(1):12.

Shende, V. (2014). Analysis of research in consumer behavior of automobile passenger car customer. International Journal of Scientific and Research Publications, 4(2).

Thakur, R. and Hale, D. (2013). Service innovation: A comparative study of US and Indian service firms. Journal of Business Research, 66(8):1108-1123.

Tracey, P. and Phillips, N. (2016). Managing the consequences of organizational stigmatization: Identity work in a social enterprise. Academy of Management Journal, 59(3):740-765.

Tustin,D.H., Ligthelm, A., Martins, J.H. and Van Wyk, H. (2005). Marketing research in practice. $1^{\text {st }}$ ed. South Africa, University of South Africa: Unisa Press.

Van Tonder, E., Petzer, D.J. and van Zyl, K. (2017). A mediated model of relationship quality factors affecting behavioural intention at a luxury motor vehicle dealership. European Business Review, 29(1):43-60.

Yanadori, Y. and Cui, V. (2013). Creating incentives for innovation? The relationship between pay dispersion in R\&D groups and organisation innovation performance. Strategic Management Journal, 34(12):1502-1511.

Zhang, M., Zhao, X., Voss, C. and Zhu, G. (2016). Innovating through services, co-creation and supplier integration: Cases from China. International Journal of Production Economics, 171:289-300. 